\title{
Microbial response to acid stress: mechanisms and applications
}

\author{
Ningzi Guan ${ }^{1}$ (D) $\cdot$ Long Liu ${ }^{2}$
}

Received: 12 August 2019 / Revised: 23 October 2019 / Accepted: 27 October 2019/Published online: 26 November 2019

(C) The Author(s) 2019

\begin{abstract}
Microorganisms encounter acid stress during multiple bioprocesses. Microbial species have therefore developed a variety of resistance mechanisms. The damage caused by acidic environments is mitigated through the maintenance of $\mathrm{pH}$ homeostasis, cell membrane integrity and fluidity, metabolic regulation, and macromolecule repair. The acid tolerance mechanisms can be used to protect probiotics against gastric acids during the process of food intake, and can enhance the biosynthesis of organic acids. The combination of systems and synthetic biology technologies offers new and wide prospects for the industrial applications of microbial acid tolerance mechanisms. In this review, we summarize acid stress response mechanisms of microbial cells, illustrate the application of microbial acid tolerance in industry, and prospect the introduction of systems and synthetic biology to further explore the acid tolerance mechanisms and construct a microbial cell factory for valuable chemicals.
\end{abstract}

Keywords Acid stress $\cdot$ Resistance mechanism $\cdot$ Probiotics $\cdot$ Organic acids $\cdot$ Systems and synthetic biology

\section{Introduction}

In the process of evolution, microorganisms have optimized growth conditions for their cellular functions. Metabolic disorders, and even cell death, can be caused by changes in the external environment such as $\mathrm{pH}$ (Beales 2004). Most microorganisms are able to survive and adapt to minor changes in environmental $\mathrm{pH}$, while induced acid tolerance may occur as the environmental $\mathrm{pH}$ declines gradually. The role of microorganisms in human life is two-sided. Some microorganisms are pathogenic and undesirable because they develop tolerance to acid stresses by adopting preventive measures (Mani-Lopez et al. 2012). In other microorganisms, such as those used in probiotics, better acid tolerance mechanisms are desired for better physiological functions (Ranadheera et al. 2014). As an environmentally friendly and renewable process, microbial synthesis of many valuable products through

Ningzi Guan

nzguan@bio.ecnu.edu.cn

1 Synthetic Biology and Biomedical Engineering Laboratory, Biomedical Synthetic Biology Research Center, Shanghai Key Laboratory of Regulatory Biology, Institute of Biomedical Sciences and School of Life Sciences, East China Normal University, Dongchuan Road 500, Shanghai 200241, China

2 Key Laboratory of Carbohydrate Chemistry and Biotechnology, Ministry of Education, Jiangnan University, Wuxi 214122, China fermentation has become an ideal substitution for traditional synthetic methods such as chemical and enzymatic synthesis. Higher acid tolerance adopted by microbial producers enhances their stability during the synthetic process in which acids accumulate (Hasunuma et al. 2011; Lipscomb et al. 2012). In both cases, namely, undesired pathogenic organisms and desired microbial producers, understanding of the underlying mechanisms of acid tolerance is vital for further applications of these microorganisms.

Organic acids are formed during most microbial fermentation processes as either products or by-products. The environment for microbial growth is acidified with the accumulation of organic acids, usually negatively affecting the productivity and titer of bioprocesses as the acids reach increasing concentrations (Ghaffar et al. 2014; Jiang et al. 2015; Wang and Yang 2013; Yáñez et al. 2008). The protonated acids may enter the cells and then dissociate into proton and corresponding ion, which leads to the increase in intracellular acidity and accelerates the metabolic disorders of the cells (Trček et al. 2015; Geng et al. 2017). Great quantities of acetic acid may be released during biomass utilization in industrial production, which also leads to the increase in acid stress. Therefore, high acid tolerance capacity is indispensable for industrial strains, especially organic acid producers, and has become one of the most important standards for strain screening. Additionally, long-term use of probiotics is widespread in consumers with increasing awareness of nutritional requirements. During the process of food intake, stresses due to the abundance of gastric 
acids in the gastrointestinal tract are major survival challenges for probiotic microbes (Mills et al. 2011). In this context, several defense systems have been developed by microorganisms to survive the acid stress.

Sophisticated mechanisms at the physiological and molecular levels have been developed by microorganisms to survive and adapt to acid stress (Fernández-Niño et al. 2015; Hosseini Nezhad et al. 2015; Ju et al. 2016; Liu et al. 2015c; Matsui and Cvitkovitch 2010), and a variety of approaches has also been deployed to unveil acid tolerance mechanisms in different microbes at different levels (He et al. 2016; Hu et al. 2017; Lee et al. 2015; Sandoval et al. 2011; Zhai et al. 2014). After understanding the patterns and mechanisms of microbial response to acid stress comprehensively, specific strategies may be tailored for improvement of microbial producers and biosynthesis of valuable chemicals. Here, we systematically summarize recent progress in the study of microbial response to acidic stress and then discuss the industrial applications of the acid tolerance mechanisms. The introduction of systems and synthetic biology to identify acid resistance elements and engineer microbial cells for further enhanced acid resistance is outlined and prospected.

\section{Resistance mechanisms}

\section{pH homeostasis}

$\mathrm{pH}$ homeostasis is the regulation of the $\mathrm{pH}$ inside and outside the cell and is an important indicator of the physiological state of cells in an acidic environment (Baker-Austin and Dopson 2007). It is critical for cell growth and metabolism, influencing the absorption and utilization of nutrients, the degradation of substrates, and the synthesis of proteins and nucleic acids (Guan et al. 2013). As illustrated in Figs. 1 and 2, the maintenance of $\mathrm{pH}$ homeostasis is a result of interactions among multiple transport systems. Electrogenic proton pumps expel protons from cells, generating a membrane potential and a $\mathrm{pH}$ gradient. The interconversion of these is regulated by cation and proton transfer via secondary transporters (Călinescu et al. 2014).

Different strategies to withstand acid stress by sustained $\mathrm{pH}$ homeostasis have evolved in microbes (He et al. 2017; Jain et al. 2013; Liu et al. 2016b; Lu et al. 2013; Miller and Maier 2014; Sohlenkamp 2017). Some yeast and bacteria maintain a relatively stable and neutral intracellular $\mathrm{pH}\left(\mathrm{pH}_{\mathrm{i}}\right)$ in the presence of constantly changing extracellular $\mathrm{pH}\left(\mathrm{pH}_{\mathrm{ex}}\right)$ and generate unfixed proton gradients (Siegumfeldt et al. 2000). However, a constant $\mathrm{pH}$ gradient is more favorable to most acid-tolerant microbes. This is because a large amount of energy must be consumed to maintain neutral $\mathrm{pH}_{\mathrm{i}}$, which severely restricts the growth and metabolism of microbes (Sun 2016). $T$ he $\mathrm{pH}_{\mathrm{i}}$ of these acid-tolerant microbes decreases with acidification of the environment, but is maintained at a higher level than $\mathrm{pH}_{\mathrm{ex}}$. Once the acid reaches a certain concentration, the $\mathrm{pH}_{\mathrm{i}}$ declines sharply, and the $\mathrm{pH}$ homeostasis is destroyed. This results in protein and DNA damage, with the cells ultimately withering (Wu et al. 2012a). Therefore, sustaining pH homeostasis is essential for microbes to survive in acidic environments.

\section{Restriction of proton permeation}

Proton motive force (PMF) is a measurement of the energy state of the cell membrane generated by a charge separation between the cytoplasm and external milieu created by membrane potential and $\mathrm{pH}$ gradient across the membrane (BakerAustin and Dopson 2007). It is a common indicative reference for controlling $\mathrm{pH}$ homeostasis, which is mainly served by $\mathrm{pH}$ gradient in the study of acid resistance (Lee and Kang 2016). It is sustained by the balance between the inflow and outflow of protons.

Protons travel into the cytoplasm through the plasma membrane and are restricted by the proton permeability and

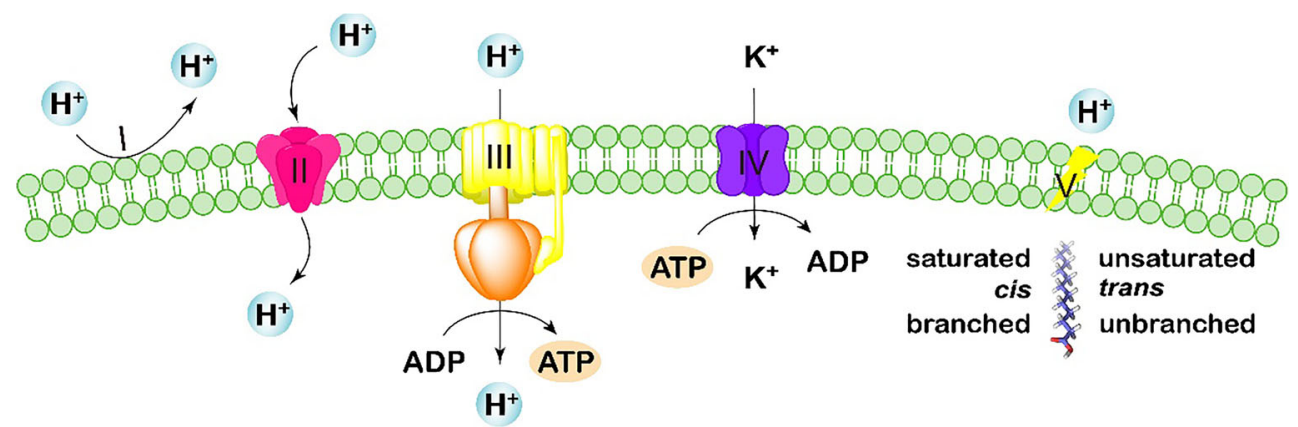

Fig. 1 Acid tolerance mechanisms associated with cell membranes and ion transport systems. Microbial cells maintain $\mathrm{pH}$ homeostasis by restricting the inward flow of protons through highly impermeable cell membranes (I) and modulating the size of membrane channels (II),

deflecting the influx of protons through generating chemiosmotic gradients via potassium ATPases (III), pumping excess protons out from the cytoplasm through proton pump (IV), and maintaining the integrity and fluidity of cell membranes by modulating fatty acid composition (V) 
Fig. 2 Enzyme-based acid tolerance mechanisms

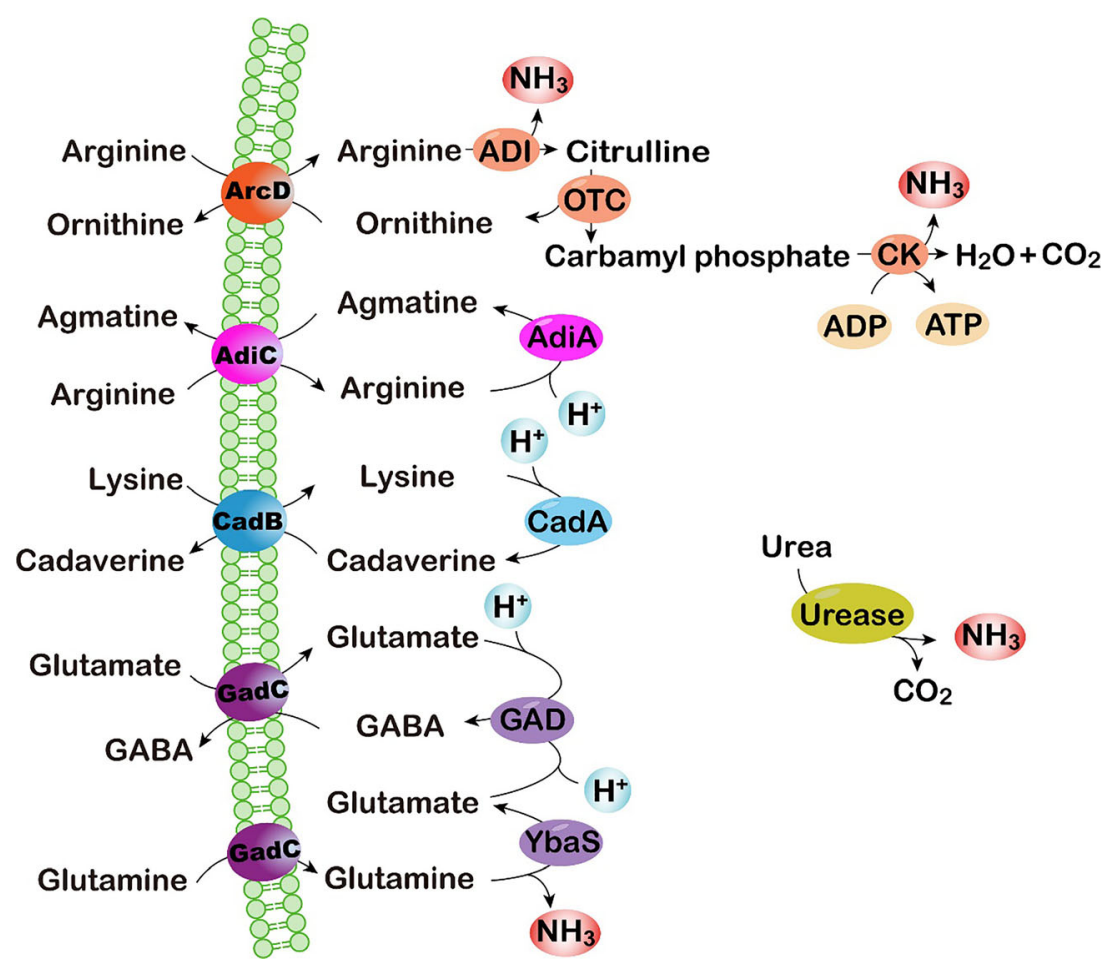

channel size of the membrane (Sohlenkamp 2017). Acidtolerant microbes are generally equipped with less permeable membranes to reduce the entry of protons into the cells (Sohlenkamp 2017). It is suggested that several factors contribute to this feature, including the tough structure of the monolayer, the bulky isoprenoid core, and a unique lipid composition such as tetraether lipids (Macalady and Banfield 2003). Modulating the size of membrane channels is another important strategy adopted by some acid-tolerant microbes to maintain $\mathrm{pH}$ homeostasis. Expression of the outer membrane porin of Acidithiobacillus ferrooxidans increased in response to acid, attempting to control the size of the porin gateway by forming a large L3 loop (Amaro et al. 1991). Consequently, the influx of protons was limited to only the outer membrane (Guiliani and Jerez 2000).

The influx of protons can also be reduced in acid-tolerant microbes using a chemiosmotic gradient generated by a Donnan potential, and the difference in electric potential formed between two solutions separated by an ion-exchange membrane without any current flow through the membrane (Baker-Austin and Dopson 2007). Many cation transporters were discovered in acidophiles, and they are presumed to be involved in the generation of a Donnan potential (Fütterer et al. 2004). Potassium transporters are reported to be the most efficient in generating chemiosmotic gradients, through which a reverse membrane potential is generated, and the inward flow of protons is restrained (Suzuki et al. 1999). It was also observed that potassium ions participate in the respirationlinked proton pump in Sulfolobus spp. (Schäfer 1996). In addition, cation ATPases (such as $\mathrm{K}^{+}$-ATPase) are involved in the maintenance of $\mathrm{pH}$ homeostasis by exchanging $\mathrm{H}^{+}$and $\mathrm{K}^{+}$ (Macpherson et al. 2005).

An interesting acid resistance mechanism of some bacteria is the formation of biofilms. It is a group behavior which involves cell to cell communication (Li et al. 2001). Biofilms protect microbial cells against acid shock through wrapping the cells in the innermost part. Hence, cell density, which is related to the formation of biofilms, is also a factor affecting the acid resistance of microorganisms (Liu et al. 2015c).

\section{Enhancement of proton pumps}

The PMF-dependent proton pump is one of the most important acid tolerance systems in bacteria in the maintenance of $\mathrm{pH}$ homeostasis, through which excess protons are pumped out from the cytoplasm (Jain et al. 2013). Several proton pumps have been shown to promote proton efflux, such as the $\mathrm{H}^{+}$-ATPase, symporter, antiporter, and secondary transporter (Sun 2016). Protons are reported to be exported from cells through $\mathrm{H}^{+}$-ATPase in bacteria, a process that consumes ATP (Sun 2016). Consequently, higher $\mathrm{H}^{+}$-ATPase activity and more energy accumulation enhance the ability of cells to regulate $\mathrm{pH}_{\mathrm{i}}$ homeostasis.

Normally, ATP is generated via $\mathrm{F}_{\mathrm{o}} \mathrm{F}_{1}$ ATPase when extracellular protons cross the cell membrane into the cytoplasm through a $\mathrm{pH}$ gradient (Sun 2016). However, the accumulation of $\mathrm{H}^{+}$leads to a sharp decrease in $\mathrm{pH}_{\mathrm{i}}$ under low $\mathrm{pH}_{\mathrm{ex}}$, and proton pumps begin ATP consumption (Fig. 1). Consequently, the energy available for cells is depleted, and the survival of 
the strain is inhibited (Zheng et al. 2011). Therefore, elevating the energy levels is an effective strategy to enhance proton pumps. Substrate-level and oxidative phosphorylation are the two ways in which microorganisms produce ATP; the latter can be enhanced by adding auxiliary energy substrates (Zhou et al. 2009). It is reported that citrate is of significance in some prokaryotic microorganisms as an auxiliary energy cosubstrate, promoting ATP regeneration (Drici et al. 2010; Kang et al. 2013). Zhou et al. were able to increase ATP supply to Candida glabrata by adding citrate to the medium and increasing $\mathrm{pH}$ gradient of the system, thus improving its acid tolerance during pyruvic acid production (Zhou et al. 2011). In short, balancing proton transport and ATP metabolism forms the core of the proton pump mechanism. Besides for bacteria and yeast, Rhizopus oryzae has also been reported to resist acid stress through $\mathrm{F}_{\mathrm{o}} \mathrm{F}_{1}$ ATPase (Liu et al. 2015b).

\section{Consumption of protons}

In addition to controlling the transmembrane proton transport, some microorganisms have developed several acid tolerance mechanisms based on the consumption of excessive cytoplasmic protons to sustain $\mathrm{pH}$ homeostasis in acidic environments. The enzyme systems of cells that generate alkaline products play key roles in these mechanisms, as illustrated in Fig. 2.

The urease system is known to neutralize $\mathrm{H}^{+}$by producing ammonia, which helps resist low $\mathrm{pH}$ during the culture of bacteria such as Helicobacter pylori (Mols and Abee 2011; Zanotti and Cendron 2010). Three models of urease have been proposed to regulate $\mathrm{pH}$ homeostasis. Originally, it was believed that urea is catalyzed by cell-associated extracellular urease and yields ammonia, which neutralizes protons around the cells (Hazell 1991). However, urease was later found to be a cytoplasmic enzyme that is released via cell lysis (Scott et al. 1998). According to the second model, ammonia produced from urease combines with $\mathrm{H}^{+}$in the periplasm and the intracellular microenvironment is maintained by increasing $\mathrm{pH}$ of the same. The current generally accepted mechanism is that urease transforms urea into ammonia and $\mathrm{CO}_{2}$, directly neutralizing protons and regulating $\mathrm{pH}_{\mathrm{i}}$ in the cytoplasm (Miller and Maier 2014). Vollan et al. found the role of $H$. pylori outer membrane phospholipase A in acid tolerance based on urea influx and ammonia efflux. This was later found to be involved in the transporting of $\mathrm{NH}_{4}{ }^{+}$into periplasm (Vollan et al. 2017).

Amino acids render several microorganisms acid-tolerant by raising the $\mathrm{pH}_{\mathrm{i}}$ during metabolism (Senouci-Rezkallah et al. 2011). Such systems have been termed amino aciddependent acid tolerance systems. The arginine deaminase (ADI) system has been identified as an important defense mechanism in several bacteria against damage by acid (Liu et al. 2015c; Shabayek and Spellerberg 2017). Three steps are involved in this system (Fig. 2). First, arginine transported into cells by ArcD is converted to citrulline and ammonia by ADI. Next, ornithine carbamoyltransferase (OTC) catalyzes the phosphorolysis of citrulline to ornithine and carbamoyl phosphate. The former is subsequently transported out of the cell, while the latter is finally converted to carbon dioxide and ammonia by carbamate kinase (CK), during which ATP is generated from ADP. Consequently, protons are neutralized by ammonia and carbon dioxide formed by the system, and the ATP produced is available to extrude protons through $\mathrm{H}^{+}$ATPase (Guan et al. 2013). Meanwhile, an arginine-agmatine antiporter AdiC and arginine decarboxylase AdiA comprise the other branch of the arginine-dependent acid tolerance system (Kanjee and Houry 2013). Arginine passes into the cell through AdiC and is converted to agmatine and carbon dioxide through catalysis by AdiA, consuming intracellular protons in the process.

The glutamate-dependent acid tolerance system is also recognized as critical for bacteria to survive in acidic environments. The function of the glutamate decarboxylase (GAD) system in acid resistance is similar to that of arginine decarboxylase (Fig. 2). Glutamate decarboxylase catalyzes the decarboxylation of glutamate, yielding $\gamma$-aminobutyric acid (GABA) and carbon dioxide, accompanied by proton consumption (Reeve and Reid 2016). The specific amino acid antiporter $\mathrm{GadC}$, which is also known to transport glutamine, transports extracellular glutamate and intracellular GABA (Laroute et al. 2016; Ma et al. 2012). Another system, comprising GadC and the glutaminase YbaS, is found in Escherichia coli (Lu et al. 2013). After being transported into the cytoplasm, glutamine is converted to glutamate and ammonia by acid-activated YbaS, following which the GAD system is initiated. Formation of alkaline products (ammonia and GABA) and the reduction of intracellular protons are the net consequences of this glutamate-related metabolism. Besides arginine and glutamate, the lysine-dependent system also plays a role in acid tolerance of cells via the decarboxylation of lysine (He et al. 2017) (Fig. 2). In addition, some other amino acids such as aspartate and citrulline are involved in the maintenance of $\mathrm{pH}_{\mathrm{i}}$ homeostasis by releasing ammonia during metabolism (Cusumano and Caparon 2015; Hu et al. 2010).

\section{Alteration of cell membranes}

The primary target of environmental stress is cell membranes, which assist in sustaining cellular activities under acidic conditions in several ways. In addition to restricting proton permeation by adjusting channel size, membrane bioenergetics and lipid physiology are also closely related to the stress response in microorganisms (Yang et al. 2014). As mentioned above, the membrane-bound $\mathrm{H}^{+}$-ATPase regulates $\mathrm{pH}_{\mathrm{i}}$ of cells by pumping protons out of the cytoplasm. Therefore, higher levels of $\mathrm{H}^{+}$-ATPase and its activity result in higher acid tolerance capacity (Zhang and Yang 2009). Modulation of the 
integrity, fluidity, and lipid composition of cell membranes are also important mechanisms that protect bacteria against the deleterious effects of acids (Yan et al. 2016).

Cell membranes provide a constant intracellular environment for cell growth and metabolism (Sohlenkamp 2017). Maintenance of proper membrane structure and function is a prerequisite for all cellular metabolic activities. Low $\mathrm{pH}$ usually leads to morphological changes in cells, which is a consequence of the damaged lipoidal cell membrane and decreased fluidity (Streit et al. 2008). The viability of cells under stress conditions is regulated by membrane status; cell membranes confer acid tolerance to cells through maintenance of their integrity and fluidity because of acid adaptation (Sohlenkamp 2017). Membrane fluidity is an integrated reflection of chain conformation, lateral and rotational diffusion, and resistance to sheer forces, and these characteristics are determined by the fatty acyl chain and head-group composition (Denich et al. 2003).

Some microbes regulate membrane fluidity by modulating fatty acid composition, since the bilayer structure can be modified by changing the distribution of fatty acids (Lindberg et al. 2013; Yang et al. 2014). The ratios of unsaturated to saturated, cis to trans unsaturated, and branched to unbranched fatty acids are all related to the acyl chain structure of glycerophospholipids. Altering the unsaturation ratio is a common mechanism employed by bacteria to control membrane fluidity. This depends on fatty acid synthesis by fatty acid synthases of the anaerobic pathways and desaturase enzymes of the aerobic pathways (Denich et al. 2003). It has been reported that higher unsaturation ratios of membrane fatty acids contribute to cell survival at low $\mathrm{pH}(\mathrm{Wu}$ et al. 2012 b). Isomerization of unsaturated fatty acids from cis to trans conformation also affects fluidity of the bacterial membrane (Tan et al. 2016). It is an energy-efficient post-synthesis lipid modification process, which occurs only in inactive cells (Diefenbach et al. 1992). Additionally, altering either the proportion or type of branching is another way in which cells modulate membrane fluidity (Kaiser et al. 2016; Sen et al. 2015). Specifically, membrane cyclopropane acyl chains were shown to be critical factors in acid tolerance in bacteria (Chang and Cronan 1999; Yang et al. 2015), where strains lacking such fatty acids were more sensitive to low $\mathrm{pH}$ (Kim et al. 2005). In addition, fatty acid chain length also plays a vital role in the response to acid stress. Strains reduce acidmediated damage to their cell membranes by lengthening their fatty acid chains (Wu et al. 2012b).

\section{Metabolic regulations}

Microorganisms have developed complex metabolic regulatory mechanisms to improve their acid tolerance during adaptation to acid environments. They upgrade their precursors, cofactors, and redox factors for survival, growth, and metabolism under acidic conditions by strengthening the glycolytic pathway (Guan et al. 2014). In a previous study, the glycolytic rate increased by $70 \%$ from pH 6.6 to 4.7 (Even et al. 2003), through changing enzyme concentrations and metabolic regulation of enzyme activities. The increase in enzyme activity compensates for the inhibition imposed by diminished $\mathrm{pH}$, and rescues normal metabolism. Simultaneously, the transcription of central metabolic pathway genes is regulated and transcript stability increases. The increase in the enzyme pool and decrease in mRNA concentrations indicate that translational regulation plays a major role in enhancing enzyme concentrations by controlling ribosome activity (Even et al. 2003).

Glycolytic rates increased by $70 \%$, and biomass synthesis was $80 \%$ less efficient at low $\mathrm{pH}$, suggesting that the energy required in maintaining the metabolism of strains increased (Even et al. 2003). A portion of the energy that is consumed assists proton pumps in the maintenance of $\mathrm{pH}_{\mathrm{i}}$ by extruding protons out of the cells. However, the available metabolic energy is limited since the rate of energy synthesis decreases upon cytoplasmic acidification. Thus, endogenous RNAs are catabolized to provide bases and ribose for the synthesis of carbon chains and energy (Siegumfeldt et al. 2000). Furthermore, amino acid catabolism is enhanced by fivefold when $\mathrm{pH}$ decreases from 6.6 to 4.7. The generation of $\mathrm{NH}_{3}$ and the consumption of intracellular $\mathrm{H}^{+}$via deamination and decarboxylation, respectively, are considered key mechanisms in bacterial resistance to acidification (Lu et al. 2013; Xiong et al. 2014). Similarly, the metabolism and accumulation of cellular polyamines are also enhanced to promote cell survival in acidic pH (Fujihara and Yoneyama 1993).

Except for the protective mechanisms against protons, acid-resistant mechanisms based on anions from the dissociation of organic acids have also been developed. The consumption of acetate has been found to enhance acetic acid tolerance of $S$. cerevisiae (Geng et al. 2017). Through expression of genes in acetate degradation pathway, resistance of $S$. cerevisiae to acetic acid was improved during fermentation (Ding et al. 2015b). That is, anions may improve acid tolerance by involving in certain metabolic pathways and influencing the metabolism of acids.

\section{Protection and repair of macromolecules}

An acid response mechanism that depends on protein synthesis has been widely observed in microorganisms (Liu et al. 2015c). Specific proteins are usually induced by acid stress to protect or repair macromolecules such as DNA and proteins. Several chaperones have been recognized as important acid tolerance factors, which are important during the synthesis, transport, folding, and degradation of proteins (Nicolaou et al. 2010). 
In the periplasm of Gram-negative bacteria, the enzymes, transporters, and transmembrane antiporters encounter more severe acid stress because they lack the protection of the inner membrane. This leads to their denaturation and aggregation (Hong et al. 2012). HdeA and HdeB are two periplasmic chaperones that have been identified to protect enteric bacteria from damage by gastric acid, while HdeA also protects bacteria against acid stress due to accumulated organic acids (Mates et al. 2007). HdeA prevents the acid-induced aggregation of proteins by binding to them at an acidic $\mathrm{pH}$, which is the condition in which the chaperone is activated (Tapley et al. 2009). HdeA is also involved in protein resolubilization and renaturation (Malki et al. 2008; Tapley et al. 2010). These proteins include transport proteins, metabolic enzymes, chaperones, lipoproteins, and proteases. Chaperones such as DegP and SurA can assist HdeA to protect proteins at low $\mathrm{pH}$ (Hong et al. 2012). They assist the recovery of protein activity by facilitating refolding during renaturation. HdeB is also an acid stress chaperone with the same functions as HdeA, although the optimum $\mathrm{pH}$ is different (Kern et al. 2007). HdeA and HdeB were recognized as the molecular chaperones that function specifically in acid tolerance (Hong et al. 2012).

Lo18 is a small membrane-associated heat shock protein that was characterized in Oenococcus oeni (Delmas et al. 2001). It improves the acid tolerance of bacteria through effectively suppressing protein aggregation, and it functions as a molecular chaperone to stabilize membrane and envelope proteins under acidic conditions (Weidmann et al. 2017). Ffh is a $54 \mathrm{kDa}$ homolog of the signal recognition particle (SRP) complex, which is an essential component of the protein translocation pathway involved in membrane and extracellular protein transport (Gutierrez et al. 1999). It is part of the acid tolerance response system, and its transcription is regulated by $\mathrm{pH}$. The lack of Ffh in Streptococcus mutans was found to lead to reduced $\mathrm{H}^{+}$-ATPase activity against a $\mathrm{pH} 5.0$ shock (Kremer et al. 2001). In addition, several other chaperones such as DnaK, DnaJ, GrpE and HrcA, GroEL and GroES, Clp proteases, and EF-Tu have been shown to facilitate the repair of proteins as molecular chaperones during acid stress (Shabayek and Spellerberg 2017).

Depurination and depyrimidination of DNA can occur because of intracellular acidification, since protonation of a base can lead to cleavage of the glycosyl bond (Calhoun and Kwon 2011). DNA repair systems have been identified in microbial cells to survive DNA damage against low $\mathrm{pH}$. recA encodes a multifunctional enzyme involved in synapsis, during which the paired DNA exchange strands (Adikesavan et al. 2011). The enzyme participates in DNA recombinational repair in E. coli, Bacillus subtilis, and H. pylori, along with RecN and AddAB (exonuclease V) (Ansari and Yamaoka 2017; Cardenas et al. 2014). The nucleotide excision repair system functions on damaged DNA produced from base modification, single-strand break, and abasic sites, and are considered the most important DNA repair system (Kisker et al. 2013). UvrABCD, DNA polymerase, and DNA ligase support the repair of acid-induced DNA damage, performing damage recognition, base excision, and gap filling (Das et al. 2015). UvrA overexpression enhanced the acetic acid tolerance and fermentation of Acetobacter pasteurianus, which is a widely used vinegar-brewing acetic acid bacteria (Zheng et al. 2018). In conclusion, the repair of damaged proteins and DNA is widely used by microbes to resist acid stress.

These mechanisms are mostly shared by various types of microorganisms. Additionally, the difference in cellular structure between prokaryotic and eukaryotic cells introduces diversity in acid-tolerant mechanisms. As eukaryote-specific organelles, mitochondria, vacuole and nucleus all play roles in acid tolerance of S. cerevisiae (Peng et al. 2017). Acid-tolerant mechanisms utilized by different microorganisms were summarized in Fig. 3 and listed in Table 1, respectively.

\section{Industrial applications of acid tolerance in microorganisms}

\section{Enhanced survival of probiotics in the gastrointestinal tract}

With improvement in quality of life, consumers are paying increased attention to their health. They now demand nutrition rather than just being adequately fed. Functional foods with potential health benefits are attracting increasing interest, wherein food-preserving microorganisms, especially probiotics, play significant roles. They do not only provide high levels of nutraceuticals to the food, but also participate in health regulation of humans by generation of functional molecules in situ in the gastrointestinal tract (Liu et al. 2017).

Several lactic acid bacteria and dairy propionibacteria have been generally regarded as safe, and fermented foods and oral agents containing lactic acid bacteria are developing rapidly as probiotics. They produce a number of valuable compounds including bacteriocins, exopolysaccharides, vitamins, and conjugated linoleic acids ( $\mathrm{Li}$ and $\mathrm{Cao} 2010$ ) and have potential health benefits including the regulation of intestinal motility and absorption, balance of intestinal microecology, reduction of inflammation, and the modulation of the immune system (Cousin et al. 2011).

The multiple health benefits of probiotics require that their metabolic activities and physiological functions are maintained in humans. The stress caused by gastric acid is one of the key challenges to their survival (Ranadheera et al. 2014). Extensive studies have revealed the acid tolerance mechanisms in these bacteria (Bustos et al. 2015; Guan et al. 2013; Shobharani and Halami 2014; Wu et al. 2012a). Through comparing acid tolerance characteristics such as $\mathrm{H}^{+}$-ATPase activity and cellular fatty acid profile, the acid tolerance of 


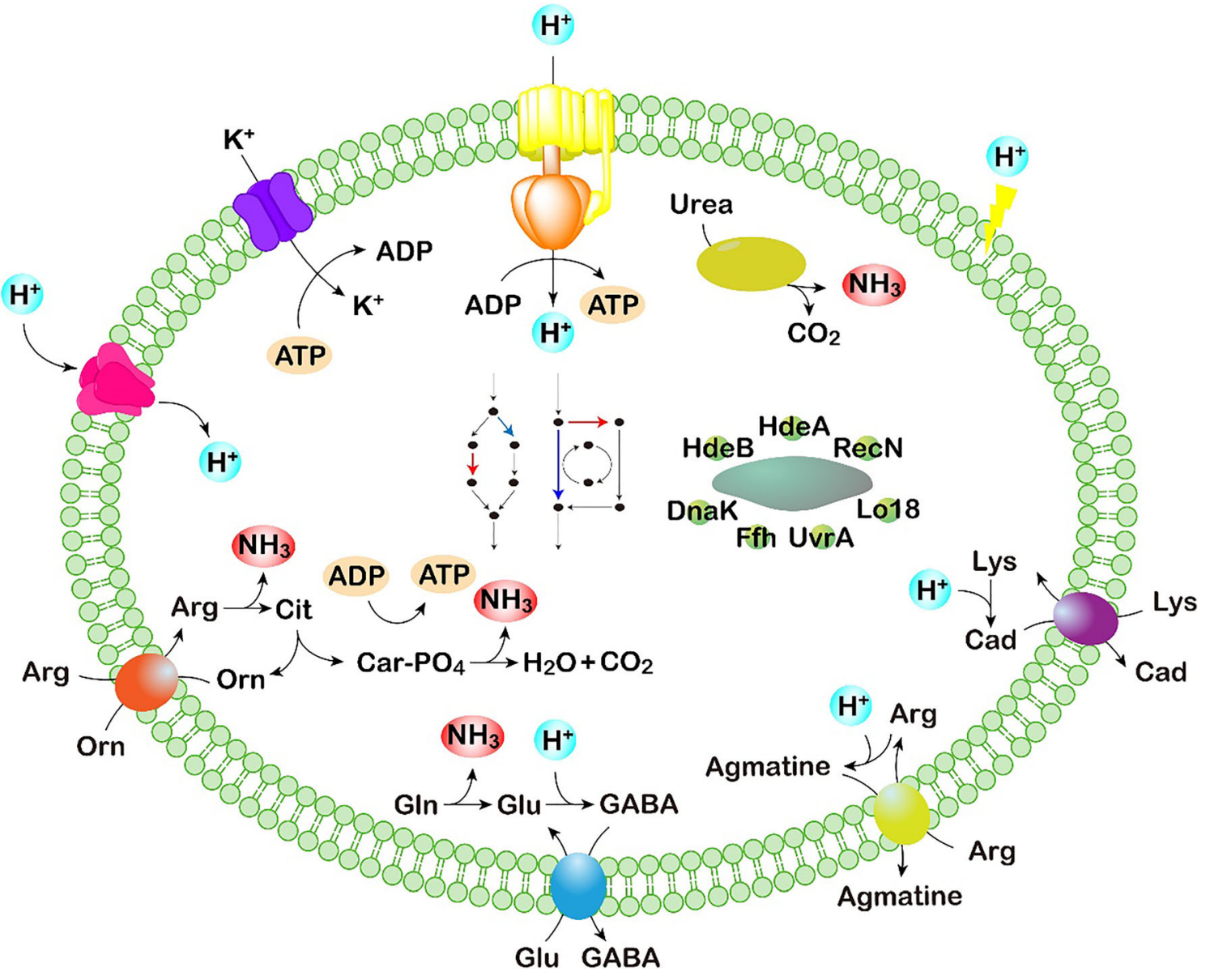

Fig. 3 Acid stress responses in microbial cells

Bacillus sp. was assessed, which provided choices and a reference for industries and consumers as possible probiotics (Shobharani and Halami 2014). Chocolate processing has been used as an effective method to improve the acid tolerance of probiotics (Labre) and make them deliverable to the intestine (Yonejima et al. 2015). Milk was employed as a suspension medium to protect probiotics such as Butyricicoccus pullicaecorum from low $\mathrm{pH}$ during the initial phase of intake (Geirnaert et al. 2014). Based on the understanding of their response to acids, strategies can be developed to protect the probiotics against acid damage, and thus enhance their survival and physiological function in humans.

\section{Enhancement of organic acid production by acid-tolerant strains}

Organic acids are important building block chemicals with increasing market demand. A variety of industrial applications has been developed for organic acids. Propionic acid (PA) is widely used in the organic synthesis of cellulose fiber, perfume, paint, herbicides, and pharmaceuticals (Liu et al. 2012). Propionibacteria are most commonly used for the biosynthesis of PA because of their vitality, high yields, capability to use a wide variety of substrates, and antimicrobial properties (Guan et al. 2015b). Various strategies have been developed to improve PA yield and productivity in propionibacteria, including the optimization of carbon sources and fermentation modes, controlling culture conditions such as $\mathrm{pH}$, oxidoreduction potential, the reduction of byproduct accumulation, and the engineering of metabolic pathways (Feng et al. 2010; Liu et al. 2015a, 2016a; Wang et al. 2015; Zhuge et al. 2013, 2014, 2015). However, it cannot meet the industry requirements. It has been reported that the accumulation of PA strongly inhibits cell growth and metabolic activity during its fermentation by propionibacteria (Guan et al. 2016). Extractive fermentation and cell immobilization have been used to enhance PA production significantly (Zhu et al. 2012). However, high osmotic pressure and potential toxicity may be induced upon extractant addition, where the low productivity and high cost of cell-immobilized fermentation is also undesirable (Liu et al. 2012). Therefore, enhancing the acid tolerance of propionibacteria is considered an effective strategy for enhanced PA production.

Currently, evolutionary engineering approaches have been applied to improve the acid tolerance and PA production of propionibacteria through random mutation. Adaptive 
Table 1 Acid-tolerant mechanisms utilized by various microorganisms

\begin{tabular}{|c|c|c|}
\hline Mechanisms & Bacteria & Yeasts \\
\hline $\mathrm{F}_{0} \mathrm{~F}_{1}$-ATPase proton pumps & $\begin{array}{l}\text { E. coli (Foster 2004; Sun et al. 2012b) } \\
\text { Lactococcus (O’Sullivan and Condon 1999) } \\
\text { Lactobacillus (Koponen et al. 2012) } \\
\text { Streptococcus (Martin-Galiano et al. 2005; } \\
\text { Kuhnert and Quivey 2003) } \\
\text { Corynebacterium glutamicum (Jakob et al. 2007) } \\
\text { P. acidipropionici (Zhang and Yang 2009; } \\
\text { Guan et al. 2013) } \\
\text { Bacillus (Shobharani and Halami 2014) }\end{array}$ & $\begin{array}{l}\text { S. cerevisiae (Casal et al. 2016) } \\
\text { C. glabrata (Zhou et al. 2011) } \\
\text { Zygosaccharomyces bailii } \\
\quad \text { (Palma et al. 2015) }\end{array}$ \\
\hline Decarboxylation and deamination & $\begin{array}{l}\text { E. coli (Iyer et al. 2003; Sun et al. 2012a; } \\
\text { Lu et al. 2013) } \\
\text { Lactococcus (Budin-Verneuil et al. 2006) } \\
\text { Lactobacillus (Su et al. 2011) } \\
\text { P. acidipropionici (Guan et al. 2013) }\end{array}$ & \\
\hline Cell membrane modification & $\begin{array}{l}\text { E. coli (Chang and Cronan 1999) } \\
\text { Lactococcus (Wu et al. 2012b) } \\
\text { Lactobacillus (Broadbent et al. 2010) }\end{array}$ & $\begin{array}{l}\text { S. cerevisiae (Ding et al. 2009; } \\
\text { Zhao and Bai 2009) } \\
\text { Z. bailii (Palma et al. 2015) }\end{array}$ \\
\hline Metabolic regulation & P. acidipropionici (Guan et al. 2014) & $\begin{array}{l}\text { S. cerevisiae (Wu et al. 2016) } \\
\text { Z. bailii (Palma et al. 2015) }\end{array}$ \\
\hline Macromolecule protection and repair & $\begin{array}{l}\text { E. coli (Hong 2012; Mujacic and Baneyx 2007) } \\
\text { Lactococcus (Weidmann et al. 2017) } \\
\text { Lactobacillus (Koponen et al. 2012) } \\
\text { Streptococcus (Shabayek and Spellerberg 2017) } \\
\text { C. glutamicum (Jakob et al. 2007) } \\
\text { A. pasteurianus (Zheng et al. 2018) }\end{array}$ & $\begin{array}{l}\text { S. cerevisiae (Ding et al. 2009) } \\
\text { Z. bailii (Palma et al. 2015) }\end{array}$ \\
\hline Protection from organelle & & $\begin{array}{l}\text { S. cerevisiae (Ding et al. 2015a; } \\
\text { Kumar et al. 2015; Cheng et al. 2016) }\end{array}$ \\
\hline
\end{tabular}

evolution is a powerful tool for strain improvement, during which the tolerant strains are repeatedly transferred into fresh broth and the $\mathrm{pH}$ is lowered gradually. The evolved strains showed higher yields and productivity of PA (Suwannakham and Yang 2005; Zhu et al. 2010). Another efficient technology of evolutionary engineering for rapid phenotype improvement is genome shuffling. Multiple superiority genes obtained from classical mutagenesis were recombined through recursive protoplast fusion. A mutant library of $P$. acidipropionici was constructed using ultraviolet irradiation and diethyl sulfate mutagenesis, followed by recursive protoplast fusion to allow recombination of genomes (Guan et al. 2012). After multiple rounds of protoplast fusion, an acid-tolerant strain was obtained, and the PA titer and productivity were enhanced by $33.3 \%$ and $65 \%$, respectively. When compared to adaptive evolution and other classical strain improvement strategies, phenotypic improvement is faster and more efficient (Guan et al. 2012).

In the absence of known specific molecular mechanisms, the improvement of acid tolerance through evolutionary engineering is limited. With the development of genetic manipulation tools, reverse engineering of tolerant phenotypes provides opportunities for further improvement of acid tolerance. First, the key factors responsible for acid tolerance must be identified. In recent years, the acid tolerance mechanisms of propionibacteria have been investigated at different levels using omics techniques. It was revealed at the microenvironment level that $P$. acidipropionici maintains $\mathrm{pH}$ homeostasis under acid stress by enhancing $\mathrm{H}^{+}$-ATPase activity and intracellular energy status (Zhang and Yang 2009). The ADI and GAD systems were also found to aid the consumption of protons (Guan et al. 2013). The key proteins and metabolites involved in acid tolerance have been identified through comparative proteomic and metabolomic analyses of the wild type P. acidipropionici and its acid-tolerant mutants (Guan et al. 2014, 2015a). In addition, genomics and transcriptomics can unveil acid tolerance-related genes and transcriptional regulators. On these bases, metabolic engineering has been performed on $P$. jensenii to improve acid resistance and PA production through overexpressing the acid-resistant elements detected by system biology (Guan et al. 2016). In conclusion, the acid-tolerant mechanisms of propionibacteria have yet to be fully elucidated systematically. Improvements in acid tolerance can yet be made to enhance PA production through rational synthetic biology approaches, and engineering microbial cells at the genetic level.

Similar to PA synthesis by propionibacteria, production of other organic acids can also be enhanced by improving the acid tolerance of strains. It has been demonstrated that acidtolerant strains are more effective in lactic acid production (Patel et al. 2006). Adaptive evolution and genome shuffling 
Table 2 Genes engineered by different microorganisms for improving acid tolerance

\begin{tabular}{|c|c|c|c|c|}
\hline Mechanisms & Genes & Microorganisms & Acid stress & References \\
\hline \multirow[t]{3}{*}{$\mathrm{F}_{0} \mathrm{~F}_{1}$-ATPase proton pumps } & AtMtATP6 & S. cerevisiae & Pyruvic acid & (Zhang et al. 2008) \\
\hline & $\operatorname{atp} A$ & P. acidipropionici & Propionic acid & (Guan et al. 2014) \\
\hline & $C g A M D 1$ & C. glabrata & Hydrochloric acid & (Wu et al. 2018) \\
\hline \multirow[t]{4}{*}{ Decarboxylation and deamination } & cad & E. coli & Acetic acid & (Noh et al. 2018) \\
\hline & $y b a S, \operatorname{gad} C$ & E. coli & Hydrochloric acid & (Lu et al. 2013) \\
\hline & $h d c A P B$ & L. lactis & Hydrochloric acid & (Trip et al. 2012) \\
\hline & $\operatorname{arc} A, \operatorname{arc} C, g d h, \operatorname{gadB}, y b a S$ & P. acidipropionici & Propionic acid & (Guan et al. 2016) \\
\hline \multirow[t]{4}{*}{ Cell membrane modification } & $c f a$ & E. coli & Hydrochloric acid & (Chang and Cronan 1999) \\
\hline & $\operatorname{mur} G$ & L. lactis & Lactic acid & (Zhang et al. 2016) \\
\hline & FPS1 & S. cerevisiae & Acetic acid & (Zhang et al. 2011) \\
\hline & Yro2, Mrh1 & S. cerevisiae & Acetic acid & (Takabatake et al. 2015) \\
\hline \multirow[t]{4}{*}{ Metabolic regulation } & $g \operatorname{sh} A, g \operatorname{sh} B$ & L. lactis & Lactic acid & (Zhang et al. 2007) \\
\hline & trePP, pgmB, ots $B$ & L. lactis & Lactic acid & (Carvalho et al. 2011) \\
\hline & BetL & Bifidobacterium breve & Gastric acid & (Sheehan et al. 2007) \\
\hline & $\mathrm{ACS} 2$ & S. cerevisiae & Acetic acid & (Ding et al. 2015b). \\
\hline \multirow[t]{4}{*}{ Macromolecule protection and repair } & $d n a K$ & L. lactis & Lactic acid & (Abdullah-Al-Mahin et al. 2010) \\
\hline & shsp & L. lactis & Lactic acid & (Tian et al. 2012) \\
\hline & $\operatorname{RecO}$ & L. lactis & Lactic acid & (Wu et al. 2013) \\
\hline & $U v r A$ & A. pasteurianus & Acetic acid & (Zheng et al. 2018) \\
\hline \multirow[t]{3}{*}{ Protection from organelle } & COX20 & S. cerevisiae & Acetic acid & (Kumar et al. 2015) \\
\hline & PEP3 & S. cerevisiae & Acetic acid & (Ding et al. 2015a) \\
\hline & RTT109 & S. cerevisiae & Acetic acid & (Cheng et al. 2016) \\
\hline
\end{tabular}

were also used to improve the acid tolerance of Lactobacillus (Patnaik et al. 2002; Zhang et al. 2012), whereby the production of lactic acid increased significantly. RNA-Seq transcriptomic analysis was performed to investigate the acid-resistant mechanisms of Acetobacter pasteurianus, providing more basics and opportunities for higher acid tolerance and acetic acid production (Yang et al. 2019). Similarly, omics were also introduced to analyze acetic acid tolerance in Saccharomyces cerevisiae (Geng et al. 2017). Improved acetic acid tolerance was obtained by modifying key genes identified, which is of great potential in industrial processes.

Acid stress is unavoidable for microorganisms during fermentation in the synthesis of the other products. Screening lactic acid bacteria with high GABA production has been performed. It is shown that low $\mathrm{pH}$ favors the activity of glutamate decarboxylase, which is important for GABA biosynthesis in lactic acid bacteria (Komatsuzaki et al. 2008). Thus, the acid-tolerant strains are most likely to produce high levels of GABA. Many studies based on the engineering of acid stress resistance in lactic acid bacteria have been performed to enhance the acid tolerance as well as lactic acid production. The glutathione synthetase genes from E. coli and the trehalose biosynthetic pathway from
P. freudenreichii were expressed in Lactococcus lactis respectively to increase survival under acid stress (Carvalho et al. 2011; Zhang et al. 2007). The histidine decarboxylation pathway, which enables cells to survive at low $\mathrm{pH}$, was also expressed in L. lactis (Trip et al. 2012). The betaine uptake system from Listeria monocytogenes was introduced into Bifidobacterium breve to increase resistance to gastric acid (Sheehan et al. 2007). The acid tolerance of L. lactis was enhanced by overexpressing molecular chaperone proteins DnaK (Tian et al. 2012) as well as the DNA repair protein $\mathrm{RecO}$ (Wu et al. 2013). Table 2 lists the genes involving in acid tolerance of microbes which have been verified through genetic manipulation.

\section{Conclusions and prospects}

Microbial cells suffer acid stress when ingested as probiotics or in the production of organic acids. Physiological and genetic resistance mechanisms have evolved in microorganisms to survive in acidic environments, including $\mathrm{pH}$ homeostasis, alteration of cell membranes, regulation of metabolism, and repair of macromolecules (Fig. 3). Although they share similar 
Fig. 4 Introduction of systems and synthetic biology to construct microbial cell factories for the improved production of organic acids

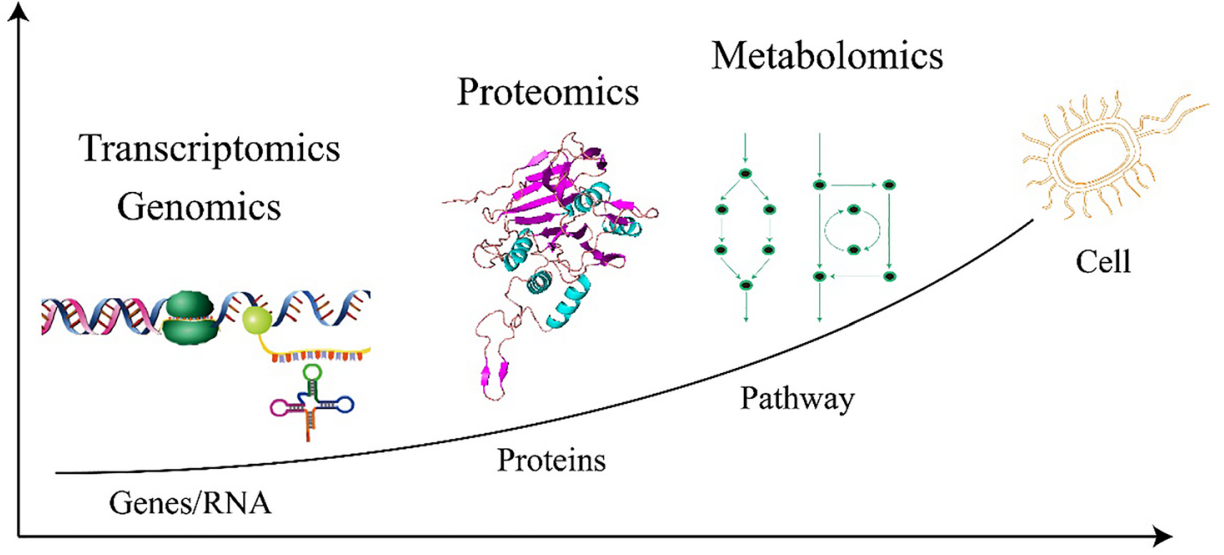

Systems Biology

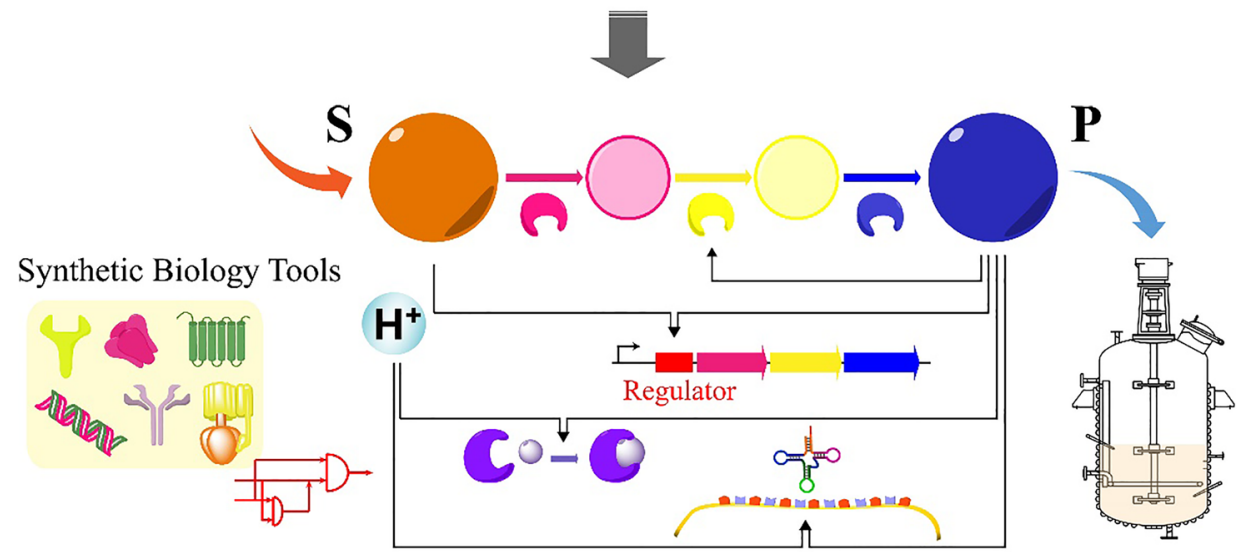

Synthetic Biology

Cell Factory resistance mechanisms, different species utilize a variety of specific elements as a response to acid stress. Therefore, customized strategies must be proposed for different strains. Currently, the acid tolerance mechanisms of microbial cells have been used in industry for improved probiotic intake and organic acid production. To further enhance the performance of industrial microorganisms, the development of effective tools to improve tolerance mechanisms is critical. The combination of systems and synthetic biology provides significant opportunities to further enhance the acid tolerance of probiotics, and construct microbial cell factories for valuable chemicals (Fig. 4). A more comprehensive understanding of microbial acid tolerance mechanisms can be obtained using systems biology technologies, and thus specific acid-tolerant elements would be uncovered. These elements can then be targeted by synthetic biology tools for improved acid tolerance and mass chemical production.

Funding information This work was financially supported by 863 projects (2015AA021005), National Natural Science Foundation of China (31622001), and the 111 Project (111-2-06).

\section{Compliance with ethical standards}

Conflict of interest The authors declare that they have no conflict of interest.

Ethical statement This article does not contain any studies with human participants or animals performed by any of the authors.

Open Access This article is distributed under the terms of the Creative Commons Attribution 4.0 International License (http:// creativecommons.org/licenses/by/4.0/), which permits unrestricted use, distribution, and reproduction in any medium, provided you give appropriate credit to the original author(s) and the source, provide a link to the Creative Commons license, and indicate if changes were made.

\section{References}

Abdullah-Al-Mahin, Sugimoto S, Higashi C, Matsumoto S, Sonomoto K. (2010) Improvement of multiple-stress tolerance and lactic acid production in Lactococcus lactis NZ9000 under conditions of thermal stress by heterologous expression of Escherichia coli dnaK. Appl Environ Microb, 76:4277-85. 
Adikesavan AK, Katsonis P, Marciano DC, Lua R, Herman C, Lichtarge O (2011) Separation of recombination and SOS response in Escherichia coli RecA suggests LexA interaction sites. PLoS Genet 7:e1002244

Amaro AM, Chamorro D, Seeger M, Arredondo R, Peirano I, Jerez CA (1991) Effect of external $\mathrm{pH}$ perturbations on in vivo protein synthesis by the acidophilic bacterium Thiobacillus ferrooxidans. J Bacteriol 173:910-915

Ansari S, Yamaoka Y (2017) Survival of Helicobacter pylori in gastric acidic territory. Helicobacter 22:e12386

Baker-Austin C, Dopson M (2007) Life in acid: pH homeostasis in acidophiles. Trends Microbiol 15:165-171

Beales N (2004) Adaptation of microorganisms to cold temperatures, weak acid preservatives, low $\mathrm{pH}$, and osmotic stress: a review. Compre Rev Food Sci F 3:1-20

Broadbent JR, Larsen RL, Deibel V, Steele JL (2010) Physiological and transcriptional response of Lactobacillus casei ATCC 334 to acid stress. J Bacteriol 192:2445-2458

Budin-Verneuil A, Maguin E, Auffray Y, Ehrlich DS, Pichereau V (2006) Genetic structure and transcriptional analysis of the arginine deiminase (ADI) cluster in Lactococcus lactis MG1363. Can J Microbiol 52:617-622

Bustos AY, de Valdez GF, Raya R, de Almeida AM, Fadda S, Taranto MP (2015) Proteomic analysis of the probiotic Lactobacillus reuteri CRL1098 reveals novel tolerance biomarkers to bile acid-induced stress. Food Res Int 77:599-607

Calhoun L, Kwon Y (2011) Structure, function and regulation of the DNA-binding protein Dps and its role in acid and oxidative stress resistance in Escherichia coli: a review. J Appl Microbiol 110:375386

Călinescu O, Paulino C, Kühlbrandt W, Fendler K (2014) Keeping it simple, transport mechanism and $\mathrm{pH}$ regulation in $\mathrm{Na}^{+} / \mathrm{H}^{+}$exchangers. J Biol Chem 289:13168-13176

Cardenas PP, Gándara C, Alonso JC (2014) DNA double strand break end-processing and RecA induce RecN expression levels in Bacillus subtilis. DNA repair 14:1-8

Carvalho AL, Cardoso FS, Bohn A, Neves AR, Santos H (2011) Engineering trehalose synthesis in Lactococcus lactis for improved stress tolerance. Appl Environ Microb 77:4189-4199

Casal M, Queirós O, Talaia G, Ribas D, Paiva S (2016) Carboxylic acids plasma membrane transporters in Saccharomyces cerevisiae. Adv Exp Med Biol 892:229-251

Chang YY, Cronan JE (1999) Membrane cyclopropane fatty acid content is a major factor in acid resistance of Escherichia coli. Mol Microbiol 33:249-259

Cheng C, Zhao XQ, Zhang MM, Bai FW. (2016). Absence of Rtt109p, a fungal-specific histone acetyltransferase, results in improved acetic acid tolerance of Saccharomyces cerevisiae. FEMS Yeast Res, 16, fow010

Cousin FJ, Mater DDG, Foligne B, Jan G (2011) Dairy propionibacteria as human probiotics: a review of recent evidence. Dairy Sci Technol 91:1-26

Cusumano ZT, Caparon MG (2015) Citrulline protects Streptococcus pyogenes from acid stress using the arginine deiminase pathway and the $\mathrm{F}_{1} \mathrm{~F}_{\mathrm{o}}$-ATPase. J Bacteriol 197:1288-1296

Das S, Ganeriwal S, Mangwani N, Patel B (2015) Survival and expression of DNA repair genes in marine bacteria Pseudomonas pseudoalcaligenes NP103 and $P$. aeruginosa N6P6 in response to environmental stressors. Microbiology 84:644-653

Delmas F, Pierre F, Coucheney F, Divies C, Guzzo J (2001) Biochemical and physiological studies of the small heat shock protein Lo 18 from the lactic acid bacterium Oenococcus oeni. J Mol Microbiol Biotechnol 3:601-610

Denich T, Beaudette L, Lee H, Trevors J (2003) Effect of selected environmental and physico-chemical factors on bacterial cytoplasmic membranes. J Microbiol Methods 52:149-182
Diefenbach R, Heipieper HJ, Keweloh H (1992) The conversion of cis into trans unsaturated fatty acids in Pseudomonas putita P8: evidence for a role in the regulation of membrane fluidity. Appl Microbiol Biotechnol 38:382-387

Ding J, Huang X, Zhang L, Zhao N, Yang D, Zhang K (2009) Tolerance and stress response to ethanol in the yeast Saccharomyces cerevisiae. Appl Microbiol Biotechnol 85:253-263

Ding J, Holzwarth G, Bradford CS, Cooley B, Yoshinaga AS, PattonVogt J, Abeliovich H, Penner MH, Bakalinsky AT (2015a) PEP3 overexpression shortens lag phase but does not alter growth rate in Saccharomyces cerevisiae exposed to acetic acid stress. Appl Microbiol Biotechnol 99:8667-8680

Ding J, Holzwarth G, Penner MH, Patton-Vogt J, Bakalinsky AT (2015b) Overexpression of acetyl-CoA synthetase in Saccharomyces cerevisiae increases acetic acid tolerance. FEMS Microbiol Lett 362:7

Drici H, Gilbert C, Kihal M, Atlan D (2010) Atypical citrate-fermenting Lactococcus lactis strains isolated from dromedary's milk. J Appl Microbiol 108:647-657

Even S, Lindley ND, Cocaign-Bousquet M (2003) Transcriptional, translational and metabolic regulation of glycolysis in Lactococcus lactis subsp. cremoris MG 1363 grown in continuous acidic cultures. Microbiology 149:1935-1944

Feng XH, Chen F, Xu H, Wu B, Yao J, Ying HJ, Ouyang PK (2010) Propionic acid fermentation by Propionibacterium freudenreichii CCTCC M207015 in a multipoint fibrous-bed bioreactor. Bioprocess Biosyst Eng 33:1077-1085

Fernández-Niño M, Marquina M, Swinnen S, Rodríguez-Porrata B, Nevoigt E, Ariño J (2015) The cytosolic pH of individual Saccharomyces cerevisiae cells is a key factor in acetic acid tolerance. Appl Environ Microb 81:7813-7821

Foster JW (2004) Escherichia coli acid resistance: tales of an amateur acidophile. Nat Rev Microbiol 2(11):898-907

Fujihara S, Yoneyama T (1993) Effects of $\mathrm{pH}$ and osmotic stress on cellular polyamine contents in the soybean rhizobia Rhizobium fredii P220 and Bradyrhizobium japonicum A1017. Appl Environ Microbiol 59:1104-1109

Fütterer O, Angelov A, Liesegang H, Gottschalk G, Schleper C, Schepers B, Dock C, Antranikian G, Liebl W (2004) Genome sequence of Picrophilus torridus and its implications for life around $\mathrm{pH}$ 0. P Natl Acad Sci USA 101:9091-9096

Geirnaert A, Steyaert A, Eeckhaut V, Debruyne B, Arends J, Immerseel FV, Boon N, de Wiele TV (2014) Butyricicoccus pullicaecorum, a butyrate producer with probiotic potential, is intrinsically tolerant to stomach and small intestine conditions. Anaerobe 30:70-74

Geng P, Zhang L, Shi GY (2017) Omics analysis of acetic acid tolerance in Saccharomyces cerevisia. Would J Microbiol Biotechnol 33:94

Ghaffar T, Irshad M, Anwar Z, Aqil T, Zulifqar Z, Tariq A, Kamran M, Ehsan N, Mehmood S (2014) Recent trends in lactic acid biotechnology: a brief review on production to purification. J Radia Res Appl Sci 7:222-229

Guan N, Liu L, Zhuge X, Xu Q, Li J, Du G, Chen J (2012) Genome shuffling improves acid tolerance of Propionibacterium acidipropionici and propionic acid production. Adv Chem Res 15: $143-152$

Guan N, Liu L, Shin H-d, Chen RR, Zhang J, Li J, Du G, Shi Z, Chen J (2013) Systems-level understanding how Propionibacterium acidipropionici respond to propionic acid stress at the microenvironment levels: mechanism and application. J Biotechnol 167:56-63

Guan N, Shin H-d, Chen RR, Li J, Liu L, Du G, Chen J (2014) Understanding of how Propionibacterium acidipropionici respond to propionic acid stress at the level of proteomics. Sci Rep 4:6951

Guan N, Li J, Shin H-d, Du G, Chen J, Liu L (2015a) Comparative metabolomics analysis of the key metabolic nodes in propionic acid synthesis in Propionibacterium acidipropionici. Metabolomics 11: 1106-1116 
Guan N, Zhuge X, Li J, Shin H-d, Wu J, Shi Z, Liu L (2015b) Engineering propionibacteria as versatile cell factories for the production of industrially important chemicals: advances, challenges, and prospects. Appl Microbiol Biotechnol 99:585-600

Guan N, Li J, Shin H-d, Du G, Chen J, Liu L (2016) Metabolic engineering of acid resistance elements to improve acid resistance and propionic acid production of Propionibacterium jensenii. Biotechnol Bioeng 113:1294-1304

Guiliani N, Jerez CA (2000) Molecular cloning, sequencing, and expression ofomp-40, the gene coding for the major outer membrane protein from the acidophilic bacterium Thiobacillus ferrooxidans. Appl Environ Microbiol 66:2318-2324

Gutierrez JA, Crowley PJ, Cvitkovitch DG, Jeannine Brady L, Hamilton IR, Hillman JD, Bleiweis AS (1999) Streptococcus mutans ffh, a gene encoding a homologue of the $54 \mathrm{kDa}$ subunit of the signal recognition particle, is involved in resistance to acid stress. Microbiology 145:357-366

Hasunuma T, Sanda T, Yamada R, Yoshimura K, Ishii J, Kondo A (2011) Metabolic pathway engineering based on metabolomics confers acetic and formic acid tolerance to a recombinant xylosefermenting strain of Saccharomyces cerevisiae. Microb Cell Factories 10:2

Hazell S (1991). Urease and catalase as virulence factors of Helicobacter pylori. In: Menge H. Helicobacter pylori 1990. Springer. p. 3-12

He G, Wu C, Huang J, Zhou R (2016) Acid tolerance response of Tetragenococcus halophilus: a combined physiological and proteomic analysis. Process Biochem 51:213-219

He A, Penix SR, Basting PJ, Griffith JM, Creamer KE, Camperchioli D, Clark MW, Gonzales AS, Sebastian Chávez Erazo J, George NS, Bhagwat AA, Slonczewski JL (2017) Acid evolution of Escherichia coli K-12 eliminates amino acid decarboxylases and reregulates catabolism. Appl Environ Microbiol 83:e00442-e00417

Hong W, Wu YE, Fu X, Chang Z (2012) Chaperone-dependent mechanisms for acid resistance in enteric bacteria. Trends Microbiol 20: $328-335$

Hosseini Nezhad M, Hussain MA, Britz ML (2015) Stress responses in probiotic Lactobacillus casei. Crit Rev Food Sci 55:740-749

$\mathrm{Hu}$ Y, Lu P, Zhang Y, Li L, Chen S (2010) Characterization of an aspartate-dependent acid survival system in Yersinia pseudotuberculosis. FEBS Lett 584:2311-2314

Hu S, Xiao X, Wu X, Xia X, Yu Y, Wu H (2017) Comparative transcriptomic analysis by RNA-seq of acid tolerance response (ATR) in EHEC O157: H7. LWT-Food Sci Technol 79:300-308

Iyer R, Williams C, Miller C (2003) Arginine-agmatine antiporter in extreme acid resistance in Escherichia coli. J Bacteriol 185:65566561

Jain PK, Jain V, Singh AK, Chauhan A, Sinha S (2013) Evaluation on the responses of succinate dehydrogenase, isocitrate dehydrogenase, malate dehydrogenase and glucose-6-phosphate dehydrogenase to acid shock generated acid tolerance in Escherichia coli. Adv Biomed Res 2:75

Jakob K, Satorhelyi P, Lange C, Wendisch VF, Silakowski B, Scherer S, Neuhaus K (2007) Gene expression analysis of Corynebacterium glutamicum subjected to long-term lactic acid adaptation. J Bacteriol 189:5582-5590

Jiang L, Cui H, Zhu L, Hu Y, Xu X, Li S, Huang H (2015) Enhanced propionic acid production from whey lactose with immobilized Propionibacterium acidipropionici and the role of trehalose synthesis in acid tolerance. Green Chem 17:250-259

Ju SY, Kim JH, Lee PC (2016) Long-term adaptive evolution of Leuconostoc mesenteroides for enhancement of lactic acid tolerance and production. Biotechnol Biofuels 9:240

Kaiser JC, Sen S, Sinha A, Wilkinson BJ, Heinrichs DE (2016) The role of two branched-chain amino acid transporters in Staphylococcus aureus growth, membrane fatty acid composition and virulence. Mol Microbiol 102:850-864
Kang TS, Korber DR, Tanaka T (2013) Contributions of citrate in redox potential maintenance and ATP production: metabolic pathways and their regulation in Lactobacillus panis PM1. Appl Microbiol Biot 97:8693-8703

Kanjee U, Houry WA (2013) Mechanisms of acid resistance in Escherichia coli. Annu Rev Microbiol 67:65-81

Kern R, Malki A, Abdallah J, Tagourti J, Richarme G (2007) Escherichia coli $\mathrm{HdeB}$ is an acid stress chaperone. J Bacteriol 189:603-610

Kim BH, Kim S, Kim HG, Lee, Lee IS, Park YK (2005) The formation of cyclopropane fatty acids in Salmonella enterica serovar Typhimurium. Microbiology 151:209-218

Kisker C, Kuper J, Van Houten B (2013) Prokaryotic nucleotide excision repair. CSH Perspect Biol 5:a012591

Komatsuzaki N, Nakamura T, Kimura T, Shima J (2008) Characterization of glutamate decarboxylase from a high $\gamma$-aminobutyric acid (GABA)-producer, Lactobacillus paracasei. Biosci Biotechnol Biochem 72:278-285

Koponen J, Laakso K, Koskenniemi K, Kankainen M, Savijoki K, Nyman TA, de Vos WM, Tynkkynen S, Kalkkinen N, Varmanen P (2012) Effect of acid stress on protein expression and phosphorylation in Lactobacillus rhamnosus GG. J Proteome 75:1357-1374

Kremer BH, van der Kraan M, Crowley PJ, Hamilton IR, Jeannine Brady L, Bleiweis AS (2001) Characterization of the sat operon in Streptococcus mutans: evidence for a role of $\mathrm{Ffh}$ in acid tolerance. J Bacteriol 183:2543-2552

Kuhnert WL, Quivey RG Jr (2003) Genetic and biochemical characterization of the F-ATPase operon from Streptococcus sanguis 10904. J Bacteriol 185:1525-1533

Kumar V, Hart AJ, Keerthiraju ER, Waldron PR, Tucker GA, Greetham D (2015) Expression of mitochondrial cytochrome c oxidase chaperone gene $(C O X 20)$ improves tolerance to weak acid and oxidative stress during yeast fermentation. PLoS One 10:16

Laroute V, Yasaro C, Narin W, Mazzoli R, Pessione E, Cocaign-Bousquet M, Loubière P (2016) GABA production in Lactococcus lactis is enhanced by arginine and co-addition of malate. Front Microbiol 7: 1050

Lee SY, Kang DH (2016) Survival mechanism of Escherichia coli O157: H7 against combined treatment with acetic acid and sodium chloride. Food Microbiol 55:95-104

Lee Y, Nasution O, Choi E, Choi IG, Kim W, Choi W (2015) Transcriptome analysis of acetic-acid-treated yeast cells identifies a large set of genes whose overexpression or deletion enhances acetic acid tolerance. Appl Microbiol Biot 99:6391-6403

Li H, Cao Y (2010) Lactic acid bacterial cell factories for gammaaminobutyric acid. Amino Acids 39:1107-1116

Li YH, Hanna MN, Svensater G, Ellen RP, Cvitkovitch DG (2001) Cell density modulates acid adaptation in Streptococcus mutans: implications for survival in biofilms. J Bacteriol 183:6875-6884

Lindberg L, Santos AX, Riezman H, Olsson L, Bettiga M (2013) Lipidomic profiling of Saccharomyces cerevisiae and Zygosaccharomyces bailii reveals critical changes in lipid composition in response to acetic acid stress. PLoS One 8:e73936

Lipscomb TW, Lipscomb ML, Gill RT, Lynch MD. (2012). Metabolic engineering of recombinant $E$. coli for the production of 3hydroxypropionate. In: Engineering complex phenotypes in industrial strains. John Wiley \& Sons, Inc. p.185-200

Liu L, Zhu Y, Li J, Wang M, Lee P, Du G, Chen J (2012) Microbial production of propionic acid from propionibacteria: current state, challenges and perspectives. Crit Rev Biotechnol 32:374-381

Liu L, Zhuge X, Shin H-d, Chen RR, Li J, Du G, Chen J (2015a) Improved production of propionic acid in Propionibacterium jensenii via combinational overexpression of glycerol dehydrogenase and malate dehydrogenase from Klebsiella pneumoniae. Appl Environ Microbiol 81:2256-2264 
Liu Y, Lv C, Xu Q, Li S, Huang H, Ouyang P (2015b) Enhanced acid tolerance of Rhizopus oryzae during fumaric acid production. Bioprocess Biosyst Eng 38:323-328

Liu Y, Tang H, Lin Z, Xu P (2015c) Mechanisms of acid tolerance in bacteria and prospects in biotechnology and bioremediation. Biotechnol Adv 33:1484-1492

Liu L, Guan N, Zhu G, Li J, Shin H-d, Du G, Chen J (2016a) Pathway engineering of Propionibacterium jensenii for improved production of propionic acid. Sci Rep 6:19963

Liu Y, Yang X, Yin Y, Lin J, Chen C, Pan J, Si M, Shen X (2016b) Mycothiol protects Corynebacterium glutamicum against acid stress via maintaining intracellular $\mathrm{pH}$ homeostasis, scavenging ROS, and S-mycothiolating MetE. J Gen Appl Microbiol 62:144-153

Liu L, Guan N, Li J, Shin H-d, Du G, Chen J (2017) Development of GRAS strains for nutraceutical production using systems and synthetic biology approaches: advances and prospects. Crit Rev Biotechnol 37:139-150

Lu P, Ma D, Chen Y, Guo Y, Chen G, Deng H, Shi Y (2013) L-glutamine provides acid resistance for Escherichia coli through enzymatic release of ammonia. Cell Res 23:635-644

Ma D, Lu P, Yan C, Fan C, Yin P, Wang J, Shi Y (2012) Structure and mechanism of a glutamate-GABA antiporter. Nature 483:632-636

Macalady J, Banfield JF (2003) Molecular geomicrobiology: genes and geochemical cycling. Earth Planet Sci Lett 209:1-17

Macpherson N, Shabala L, Rooney H, Jarman MG, Davies JM (2005) Plasma membrane $\mathrm{H}^{+}$and $\mathrm{K}^{+}$transporters are involved in the weakacid preservative response of disparate food spoilage yeasts. Microbiology 151:1995-2003

Malki A, Le H-T, Milles S, Kern R, Caldas T, Abdallah J, Richarme G (2008) Solubilization of protein aggregates by the acid stress chaperones HdeA and HdeB. J Biol Chem 283:13679-13687

Mani-Lopez E, García HS, López-Malo A (2012) Organic acids as antimicrobials to control Salmonella in meat and poultry products. Food Res Int 45:713-721

Martín-Galiano AJ, Overweg K, Ferrándiz MJ, Reuter M, Wells JM, de la Campa AG (2005) Transcriptional analysis of the acid tolerance response in Streptococcus pneumonia. Microbiology 151:39353946

Mates AK, Sayed AK, Foster JW (2007) Products of the Escherichia coli acid fitness island attenuate metabolite stress at extremely low $\mathrm{pH}$ and mediate a cell density-dependent acid resistance. J Bacteriol 189:2759-2768

Matsui R, Cvitkovitch D (2010) Acid tolerance mechanisms utilized by Streptococcus mutans. Future Microbiol 5:403-417

Miller EF, Maier RJ (2014) Ammonium metabolism enzymes aid Helicobacter pylori acid resistance. J Bacteriol 196:3074-3081

Mills S, Stanton C, Fitzgerald GF, Ross RP (2011) Enhancing the stress responses of probiotics for a lifestyle from gut to product and back again. Microb Cell Factories 10:S19

Mols M, Abee T (2011) Bacillus cereus responses to acid stress. Environ Microbiol 13:2835-2843

Mujacic M, Baneyx F (2007) Chaperone Hsp31 contributes to acid resistance in stationary-phase Escherichia coli. Appl Environ Microbiol 73:1014-1018

Nicolaou SA, Gaida SM, Papoutsakis ET (2010) A comparative view of metabolite and substrate stress and tolerance in microbial bioprocessing: from biofuels and chemicals, to biocatalysis and bioremediation. Metab Eng 12:307-331

Noh MH, Lim HG, Woo SH, Song J, Jung GY (2018) Production of itaconic acid from acetate by engineering acid-tolerant Escherichia coli W. Biotechnol Bioeng 115:729-738

O'Sullivan E, Condon S (1999) Relationship between acid tolerance, cytoplasmic $\mathrm{pH}$, and ATP and $\mathrm{H}^{+}$-ATPase levels in chemostat cultures of Lactococcus lactis. Appl Environ Microbiol 65:2287-2293

Palma M, de Canaveira RF, Guerreiro JF, Mira NP, Queiroz L, Sá-Correia I (2015) Search for genes responsible for the remarkably high acetic acid tolerance of a Zygosaccharomyces bailii-derived interspecies hybrid strain. BMC Genomics 16:1070

Patel MA, Ou MS, Harbrucker R, Aldrich HC, Buszko ML, Ingram LO, Shanmugam KT (2006) Isolation and characterization of acid-tolerant, thermophilic bacteria for effective fermentation of biomassderived sugars to lactic acid. Appl Environ Microbiol 72:3228-3235

Patnaik R, Louie S, Gavrilovic V, Perry K, Stemmer WPC, Ryan CM, del Cardayré S (2002) Genome shuffling of Lactobacillus for improved acid tolerance. Nat Biotechnol 20:707-712

Ranadheera CS, Evans CA, Adams MC, Baines SK (2014) Effect of dairy probiotic combinations on in vitro gastrointestinal tolerance, intestinal epithelial cell adhesion and cytokine secretion. J Funct Foods 8: $18-25$

Reeve B, Reid S (2016) Glutamate and histidine improve both solvent yields and the acid tolerance response of Clostridium beijerinckii NCP 260. J Appl Microbiol 120:1271-1281

Sandoval NR, Mills TY, Zhang M, Gill RT (2011) Elucidating acetate tolerance in E. coli using a genome-wide approach. Metab Eng 13: 214-224

Schäfer G (1996) Bioenergetics of the archaebacterium Sulfolobus. Biochim Biophys Acta Bioenerg 1277:163-200

Scott DR, Weeks D, Hong C, Postius S, Melchers K, Sachs G (1998) The role of internal urease in acid resistance of Helicobacter pylori. Gastroenterology 114:58-70

Sen S, Sirobhushanam S, Hantak MP, Lawrence P, Thomas Brenna J, Gatto C, WilkinsonBJ (2015) Short branched-chain C6 carboxylic acids result in increased growth, novel 'unnatural' fatty acids and increased membrane fluidity in a listeria monocytogenes branchedchain fatty acid-deficient mutant. BBA-Mol Cell Biol L 1851:14061415

Senouci-Rezkallah K, Schmitt P, Jobin MP (2011) Amino acids improve acid tolerance and internal $\mathrm{pH}$ maintenance in Bacillus cereus ATCC14579 strain. Food Microbiol 28:364-372

Shabayek S, Spellerberg B (2017) Acid stress response mechanisms of group B Streptococci. Front Cell Infect Microbiol 7:395

Sheehan VM, Sleator RD, Hill C, Fitzgerald GF (2007) Improving gastric transit, gastrointestinal persistence and therapeutic efficacy of the probiotic strain Bifidobacterium breve UCC2003. Microbiology 153:3563-3571

Shobharani P, Halami PM (2014) Cellular fatty acid profile and $\mathrm{H}^{+}$ATPase activity to assess acid tolerance of Bacillus sp. for potential probiotic functional attributes. Appl Microbiol Biot 98:9045-9058

Siegumfeldt H, Rechinger KB, Jakobsen M (2000) Dynamic changes of intracellular $\mathrm{pH}$ in individual lactic acid bacterium cells in response to a rapid drop in extracellular pH. Appl Environ Microbiol 66: $2330-2335$

Sohlenkamp C (2017) Membrane homeostasis in bacteria upon ph challenge. In: Biogenesis of fatty acids. Springer, Lipids and Membranes, pp 1-13

Streit F, Delettre J, Corrieu G, Béal C (2008) Acid adaptation of Lactobacillus delbrueckii subsp. bulgaricus induces physiological responses at membrane and cytosolic levels that improves cryotolerance. J Appl Microbiol 105:1071-1080

Su MS, Schlicht S, Gänzle MG (2011) Contribution of glutamate decarboxylase in Lactobacillus reuteri to acid resistance and persistence in sourdough fermentation. Microb Cell Factories 10:S8

Sun $\mathrm{Y}$ (2016). $\mathrm{F}_{1} \mathrm{~F}_{0}$-ATPase functions under markedly acidic conditions in bacteria. In: Regulation of $\mathrm{Ca}^{2+}$-ATPases, V-ATPases and FATPases. Springer. p. 459-68

Sun Y, Fukamachi T, Saito H, Kobayashi H (2012a) Adenosine deamination increases the survival under acidic conditions in Escherichia coli. J Appl Microbiol 112:775-781

Sun Y, Fukamachi T, Saito H, Kobayashi H (2012b) Respiration and the $\mathrm{F}_{1}$ Fo-ATPase enhance survival under acidic conditions in Escherichia coli. PLoS One 7:e52577 
Suwannakham S, Yang ST (2005) Enhanced propionic acid fermentation by Propionibacterium acidipropionici mutant obtained by adaptation in a fibrousbed bioreactor. Biotechnol Bioeng 91:325-337

Suzuki I, Lee D, Mackay B, Harahuc L, Oh JK (1999) Effect of various ions, $\mathrm{pH}$, and osmotic pressure on oxidation of elemental sulfur by Thiobacillus thiooxidans. Appl Environ Microbiol 65:5163-5168

Takabatake A, Kawazoe N, Izawa S (2015) Plasma membrane proteins Yro2 and Mrh1 are required for acetic acid tolerance in Saccharomyces cerevisiae. Appl Microbiol Biotechnol 99:2805-2814

Tan Z, Yoon JM, Nielsen DR, Shanks JV, Jarboe LR (2016) Membrane engineering via trans unsaturated fatty acids production improves Escherichia coli robustness and production of biorenewables. Metab Eng 35:105-113

Tapley TL, Körner JL, Barge MT, Hupfeld J, Schauerte JA, Gafni A, Jakob U, Bardwell JCA (2009) Structural plasticity of an acidactivated chaperone allows promiscuous substrate binding. P Natl Acad Sci 106:5557-5562

Tapley TL, Franzmann TM, Chakraborty S, Jakob U, Bardwell JC (2010) Protein refolding by $\mathrm{pH}$-triggered chaperone binding and release. $\mathrm{P}$ Natl Acad Sci 107:1071-1076

Tian H, Tan J, Zhang L, Gu X, Xu W, Guo X, Luo Y (2012) Increase of stress resistance in Lactococcus lactis via a novel food-grade vector expressing a shsp gene from Streptococcus thermophilus. Braz J Microbiol 43:1157-1164

Trček J, Mira NP, Jarboe LR (2015) Adaptation and tolerance of bacteria against acetic acid. Appl Microbiol Biotechnol 99:6215-6229

Trip H, Mulder NL, Lolkema JS (2012) Improved acid stress survival of Lactococcus lactis expressing the histidine decarboxylation pathway of Streptococcus thermophilus CHCC1524. J Biol Chem 287: 11195-11204

Vollan HS, Tannæs T, Caugant DA, Vriend G, Bukholm G (2017) Outer membrane phospholipase A's roles in Helicobacter pylori acid adaptation. Gut pathog 9:36

Wang Z, Yang S-T (2013) Propionic acid production in glycerol/glucose co-fermentation by Propionibacterium freudenreichii subsp. shermanii. Bioresour Technol 137:116-123

Wang Z, Ammar EM, Zhang A, Wang L, Lin M, Yang ST (2015) Engineering Propionibacterium freudenreichii subsp. shermanii for enhanced propionic acid fermentation: effects of overexpressing propionyl-CoA: succinate CoA transferase. Metab Eng 27:46-56

Weidmann S, Maitre M, Laurent J, Coucheney F, Rieu A, Guzzo J (2017) Production of the small heat shock protein Lo18 from Oenococcus oeni in Lactococcus lactis improves its stress tolerance. Int J Food Microbiol 247:18-23

Wu C, Zhang J, Chen W, Wang M, Du G, Chen J (2012a) A combined physiological and proteomic approach to reveal lactic-acid-induced alterations in Lactobacillus casei Zhang and its mutant with enhanced lactic acid tolerance. Appl Microbiol Biotechnol 93:707-722

Wu C, Zhang J, Wang M, Du G, Chen J (2012b) Lactobacillus casei combats acid stress by maintaining cell membrane functionality. $\mathrm{J}$ Ind Microbiol Biot 39:1031-1039

Wu C, Zhang J, Du G, Chen J (2013) Heterologous expression of Lactobacillus casei RecO improved the multiple-stress tolerance and lactic acid production in Lactococcus lactis NZ9000 during salt stress. Bioresour Technol 143:238-241

Wu XC, Zhang LJ, Jin XN, Fang YH, Zhang K, Qi L, Zheng DQ (2016) Deletion of JJJ1 improves acetic acid tolerance and bioethanol fermentation performance of Saccharomyces cerevisiae strains. Biotechnol Lett 38:1097-1106

Wu J, Luo Q, Liu J, Chen X, Liu L (2018) Enhanced pyruvate production in Candida glabrata by overexpressing the CgAMD1 gene to improve acid tolerance. Biotechnol Lett 40:143-149

Xiong L, Teng JL, Watt RM, Kan B, Lau SK, Woo PC. (2014) Arginine deiminase pathway is far more important than urease for acid resistance and intracellular survival in Laribacter hongkongensis: a possible result of arc gene cassette duplication. BMC Microbiol 14:42
Yan D, Lin X, Qi Y, Liu H, Chen X, Liu L, Chen J (2016) Crzlp regulates $\mathrm{pH}$ homeostasis in Candida glabrata by altering membrane lipid composition. Appl Environ Microbiol 82:6920-6929

Yáñez R, Marques S, Gírio FM, Roseiro JC (2008) The effect of acid stress on lactate production and growth kinetics in Lactobacillus rhamnosus cultures. Process Biochem 43:356-361

Yang YS, Kadim MI, Khoo WJ, Zheng Q, Setyawati MI, Shin Y-J, Lee SC, Yuk H-G (2014) Membrane lipid composition and stress/ virulence related gene expression of Salmonella Enteritidis cells adapted to lactic acid and trisodium phosphate and their resistance to lethal heat and acid stress. Int J Food Microbiol 191:24-31

Yang X, Hang X, Zhang M, Liu X, Yang H (2015) Relationship between acid tolerance and cell membrane in Bifidobacterium, revealed by comparative analysis of acid-resistant derivatives and their parental strains grown in medium with and without Tween 80. Appl Microbiol Biot 99:5227-5236

Yang H, Yu Y, Fu C, Chen F (2019) Bacterial acid resistance toward organic weak acid revealed by rna-seq transcriptomic analysis in Acetobacter pasteurianus. Front Microbiol 10:1616

Yonejima Y, Hisa K, Kawaguchi M, Ashitani H, Koyama T, Usamikrank Y, Kishida N, Kishino S, Ogawa J (2015) Lactic acid bacteriacontaining chocolate as a practical probiotic product with increased acid tolerance. Biocatalysis Agric Biotechnol 4:773-777

Zanotti G, Cendron L (2010) Functional and structural aspects of Helicobacter pylori acidic stress response factors. IUBMB Life 62:715-723

Zhai Z, Douillard FP, An H, Wang G, Guo X, Luo Y, Hao Y (2014) Proteomic characterization of the acid tolerance response in Lactobacillus delbrueckii subsp. bulgaricus CAUH1 and functional identification of a novel acid stress-related transcriptional regulator Ldb0677. Environ Microbiol 16:1524-1537

Zhang A, Yang ST (2009) Engineering Propionibacterium acidipropionici for enhanced propionic acid tolerance and fermentation. Biotechnol Bioeng 104:766-773

Zhang J, Fu R-Y, Hugenholtz J, Li Y, Chen J (2007) Glutathione protects Lactococcus lactis against acid stress. Appl Environ Microb 73: 5268-5275

Zhang X, Liu S, Takano T (2008) Overexpression of a mitochondrial ATP synthase small subunit gene (AtMtATP6) confers tolerance to several abiotic stresses in Saccharomyces cerevisiae and Arabidopsis thaliana. Biotechnol Lett 30:1289-1294

Zhang JG, Liu XY, He XP, Guo XN, Lu Y, Zhang BR (2011) Improvement of acetic acid tolerance and fermentation performance of Saccharomyces cerevisiae by disruption of the FPS1 aquaglyceroporin gene. Biotechnol Lett 33:277-284

Zhang J, Wu C, Du G, Chen J (2012) Enhanced acid tolerance in Lactobacillus casei by adaptive evolution and compared stress response during acid stress. Biotechnol Bioproc E 17:283-289

Zhang J, Caiyin Q, Feng W, Zhao X, Qiao B, Zhao G, Qiao J (2016) Enhance nisin yield via improving acid-tolerant capability of Lactococcus lactis F44. Sci Rep 6:27973

Zhao XQ, Bai FW (2009) Mechanisms of yeast stress tolerance and its manipulation for efficient fuel ethanol production. J Biotechnol 144: 23-30

Zheng D, Wu X, Wang P, Chi X, Tao X, Li P, Jiang X, Zhao Y (2011) Drug resistance marker-aided genome shuffling to improve acetic acid tolerance in Saccharomyces cerevisiae. J Ind Microbiol Biot 38: 415-422

Zheng Y, Wang J, Bai X, Chang Y, Mou J, Song J, Wang M (2018) Improving the acetic acid tolerance and fermentation of Acetobacter pasteurianus by nucleotide excision repair protein UvrA. Appl Microbiol Biotechnol 102:6493-6502

Zhou J, Liu L, Shi Z, Du G, Chen J (2009) ATP in current biotechnology: regulation, applications and perspectives. Biotechnol Adv 27:94 101 
Zhou J, Liu L, Chen J (2011) Improved ATP supply enhances acid tolerance of Candida glabrata during pyruvic acid production. J Appl Microbiol 110:44-53

Zhu Y, Li J, Tan M, Liu L, Jiang L, Sun J, Lee P, Du G, Chen J (2010) Optimization and scale-up of propionic acid production by propionic acid-tolerant Propionibacterium acidipropionici with glycerol as the carbon source. Bioresour Technol 101:8902-8906

Zhu L, Wei P, Cai J, Zhu X, Wang Z, Huang L, Xu Z (2012) Improving the productivity of propionic acid with FBB-immobilized cells of an adapted acid-tolerant Propionibacterium acidipropionici. Bioresour Technol 112:248-253

Zhuge X, Liu L, Shin H-d, Chen RR, Li J, Du G, Chen J (2013) Development of a Propionibacterium-Escherichia coli shuttle vector as a useful tool for metabolic engineering of Propionibacterium jensenii, an efficient producer of propionic acid. Appl Environ Microbiol 80:4595-4602

Zhuge X, Liu L, Shin H-d, Li J, Du G, Chen J (2014) Improved propionic acid production from glycerol with metabolically engineered Propionibacterium jensenii by integrating fed-batch culture with a pH-shift control strategy. Bioresour Technol 152:519-525

Zhuge X, Li J, Shin H-d, Liu L, Du G, Chen J (2015) Improved propionic acid production with metabolically engineered Propionibacterium jensenii by an oxidoreduction potential-shift control strategy. Bioresour Technol 175:606-612

Publisher's note Springer Nature remains neutral with regard to jurisdictional claims in published maps and institutional affiliations. 